\title{
Study on Yimeng Spirit and Its Contemporary Value
}

\author{
Xianhua Meng \\ Feixian College \\ Linyi University \\ Feixian, Linyi, Shandong, China
}

\begin{abstract}
Yimeng spirit is a tradition cultivated by the integration of the certain historical conditions, as well as a cultural core and a spiritual temperament composed by longterm deposits, condensation and sublimation. Confucian tradition has provided the most profound background for it; the regional culture has provided the most basic quality for it; the red culture of the Chinese revolution has provided a new connotation for it; the new cultural tradition cultivated by the innovation of reform and opening up has poured strong vitality and energy into it. Yimeng spirit, rooting in the land and fertile soil of Yimeng Mountain, possesses the nature of grassroots and popularity. It is generated among people, and it must also return back into people, so that it can become a live and animate existence. Yimeng spirit, with the penetrating power of history, has played an important role in the great rejuvenation of Chinese nation.
\end{abstract}

Keywords-Yimeng spirit; historical and cultural deposits; the mass base; the contemporary value

\section{INTRODUCTION}

Yimeng spirit, to some extent, is a traditional culture represented by Confucian, a regional culture symbolized by Yimeng Mountain and also a red culture symbolized by extremely hard and bitter struggle and sacrifice in revolutionary war times; it is also a times culture led by the forging ahead and perseverance of reform and opening up; it can be regarded as a tradition developed by the integration on a certain historical condition; by other words, it can be referred as a cultural core and a spiritual temperament composed by the long-term deposits, condensation and sublimation of the elements mentioned above. The spirit is undoubtedly a complex of deep and rich connotation, with characteristics, such as multi-dimension, multi-level, and multi-element. Yimeng spirit generally shows a series of spiritual qualities, such as perseverance, no fear on sacrifice, courage of dedication, insistence on dreams, simple and honest kindness, gentleness and sincerity, etc. It belongs to a region, but is not limited to the region; it belongs to the people of Yimeng Mountain, but is not limited to those people; it belongs to a time, but is not limited to that time. It is the result made by the two-way selection, mutual conjunction and integration of tradition and times; it is the essence gathering the massiveness of traditions and the revolution of the times. The spirit is not only an excellent cultural heritage, but also a live and animate culture blood. It is the spiritual trait accumulated by the people of Yimeng Mountain for a long time, and it has also become an important part of the Chinese national spirit permeating and radiating other regions through summarizing and publicity, its own charm, and other different paths, such as interpersonal communication.

That is to say that Yimeng spirit is not only a form concentrated from Chinese National spirit under a certain space-time condition, but also a time spirit created by Yimeng People through the extremely hard struggle and construction practice under the leadership of Chinese Communist Party. Its cultivation, in reverse, further enriches and deepens the connotation and implication, and it has become the immortal spiritual wealth and cultural value of Chinese nation.

\section{CULTURAL AND HisTORICAL DEPOSITS OF YIMENG SPIRIT}

Yimeng spirit has profound historical deposits and deep cultural deposits. So to speak, the Confucian tradition has provided the spirit the deepest ground color; the regional culture (the spiritual qualities cultivated by the unique local customs and practices of Yimeng Mountain) has provided it the most basic quality; the Chinese red culture has provided it a new connotation; the new cultural tradition formed by the development and innovation of reform and opening up has provided it strong vitality and energy.

Meng Mountain and Yi River are a high mountain and a long river. Confucius said, "Wise ones enjoy rivers, while kind ones enjoy mountains; wise ones are dynamic, while kind ones are quiet; wise ones are of happiness, while kind ones are of long life." (The Analects -- Ranyong) there are mountains and rivers in the region of Yimeng Mountain. This kind of unique geographical environment has decided and cultivated the unique cultural personality at the origin of its civilization. The cultural personality included the tension structure of the complementation of economy and power, the coupling of hardness and softness, and the complementation of Yin and Yang, which provided the cultural prototype for the complete gentleman personality. Wise people keep forging ahead, while kind people keep honesty and sincerity. As The Commentaries on the Book of Changes goes, "the man of honor will strive constantly for self-improvement. The power of the earth is what is denoted by Kun. Therefore, the man of honor supports people and things with his virtue." As the land of ancient Langya, Yimeng Mountain has extremely deep and rich accumulation of traditional culture. On the aspect of regional distribution, the place called Linyi 
belonged to the state of Qi and the state of Lu separately, during the Spring and Autumn Period and Warring States Period, so the personalities of the cultures of Qi and Lu were inherited. If the value orientation of Qi culture is regarded as stressing on "respecting able and virtuous people and achievements", the value orientation of $\mathrm{Lu}$ culture can be regarded as stressing on "you will get more grace, if you get close to noble people". Comparing those two kinds of culture, we can find that they both have their own strengths and weaknesses. The tension structure cultivated by their tension and relaxation, as well as expanding and restraining, has an irreplaceable value of inspiration on the cultural choices we are facing during the process of modernization and the overall cultivation of cultural consciousness. The state of Qi advocated to rule by law, while the state of Lu advocated to rule by rites. The two different cultural traditions have exactly provided the historical reference for us to coordinate the relationship between "virtue" and "law".

During the Anti-Japanese War Period, a set of heroic deeds sprang out in the region of Yimeng Mountain. The life-and-death fight of villagers of Yuanzi Cliff against Japanese invaders is one of the typical heroic deeds. During the liberation war period, it is said by statistics that around 200 thousand people among 4.6 million people in the entire Linyi region joined the army, and more than 1 million people joined the army to "support the frontline", and more than 60 thousand people sacrificed on the land. Yimeng people have made great sacrifice and immortal dedication for the liberation of Chinese nation and the set-up of New China. During the period of socialist construction, a great number of advanced typical examples sprang up on the land, such as the hard exploration and successful experience of Li Family Village, Wang Family Lane Front and Gao Family Willow Trench instructed by Chairman Mao, as well as the enterprising deeds of Nine-Shed Village, etc. All those, such as Yimeng people's selfless contribution, heroic performance of no fear to sacrifice, hardworking, and practicing without any fear and hesitation, are not just real sacrifices, but has been sublimated as a spiritual value, fusing into the construction of Yimeng spirit.

\section{The MASS BASE OF YIMENG SPIRIT}

Yimeng spirit is of deep mass base. It has rooted in the land and the soil of Yimeng Mountain, with the nature of grassroots and popularity. It was generated from people, and it must return to the people, so that it can become a live and animate existence.

Marx and Engels pointed out, "historical activities are the cause of the masses. With the deepening of historical activities, the mass procession will certainly grow bigger." Marxist historical materialism opposes hero-dominant historical view, and insists on view of people determining history and historical view of the masses. It is firstly the appeal determined by the class nature of Marxist philosophy, because "all the past activities were activities for the minority or their benefits. Proletarian activities are independent activities for the majority and their benefits." At the same time, it is also the trait determined by the academic and theoretical basis of Marxist philosophy. The category of practice is set by Marx on the ultimate original place in his entire philosophical system, and the masses as the creator of the history constructs the main body of practice. Therefore, view of people determining history and historical view of the masses are the inner demands of historical materialism and the inexorable outcome of practical materialism. Lenin said, "People with wonderful spiritual qualities are the minority, while people who can determine the historical ending are the masses." In addition, Mao Zedong addressed, "people, only people, can be the motivation of creating the world's history." It is on the basis that Chinese Communist Party have founded the mass line of "all for the masses, all relying on the masses, and all from the masses going back to the masses".

Yimeng spirit itself is the creation of the masses, and has its deep and wide folk soil to grow. It is better to say the spirit is the spiritual fruit produced by the perseverance of millions of Yimeng people. Only during their historical liberation, the positivity and the historical pioneering spirit can be maximally induced and promoted, which is the clearly showed during the process of the creating of Yimeng spirit. In the book On Protracted War, Mao Zedong mentioned that "the army and the people are the base of victory", and also stressed that "the deep origin of the great power of war exist among the masses". Those principles work for both revolutionary war and peaceful construction. Therefore, "the view of the masses is the starting point and the destination of the revolution of communists. Coming from the masses and going back to the masses. It will be good to handle if the problems are thought from the view of the masses." Whether it is war time or the peaceful construction time, the principle is an incontrovertible truth.

Yimeng spirit itself is the historical creation of the masses; meanwhile, only when controlled by the masses, can the spirit become the great material power. It is live and animate, not the "cultural relic for watching or an "antique"; it is only practical, which means only people's practicing and the unity of knowing and doing can make it genuinely exist and continuously be spread and grow greater.

\section{THE CONTEMPORAR Y VALUE OF YimENG SPIRIT}

Yimeng spirit possesses the penetrating power of the history. During the great rejuvenation, Yimeng spirit will certainly play an important role. The spiritual qualities included in it should be carried forward. Under the background of marketization and globalization, its immortal value is further highlighted. As an invisible wealth, Yimeng spirit has been condensed as an immortal power. No matter what situation it is, the spirit will encourage and inspire us to confront with any possible risk and challenge positively. The specific forms of difficulties and setbacks may be quite different, but the spirits they demand are the same. Seen from the surface, Yimeng spirit seems a little bit left behind on some aspects, but the truth is it isn't. The deepening and developing of market economy has more need of people's down-to-earth striving. As the time gets matured, the value of Yimeng spirit will be more highlighted. On the contemporary historical conditions, Yimeng spirit has 
meanings and value on many aspects. Some important aspects are selected and showed as follows:

Firstly, carrying forward Yimeng spirit is beneficial for us to consciously inherit and implement the mass line of the party under the new historical conditions. Insist on the mass viewpoint, keep close links with the masses, and go the mass line, which is essentially the meaning included in Yimeng spirit, and which is really carrying forward Yimeng spirit. To insist on the mass line, a right attitude is necessary and the truth should be indeed realized --- "the masses are real heroes. However, we are always childish and funny ourselves. If we have no idea about the truth, we cannot get the basic knowledge." The historical experience condensed in Yimeng spirit and the historical truth reflected from the spirit tell us that only when we respect the pioneering spirit of the masses and rely on the masses as a metal wall, will we win the victory and the success of revolutions and construction business.

Secondly, carrying forward Yimeng spirit is beneficial for us to strengthen the immunity of morality during the process of marketization, which has a vital meaning on defending moral value and saving human souls. To some significance, market economy is still one of the most effective institutional arrangement to allocate scarce resources between men, and it undoubtedly will bring huge material wealth and constitute the economic basis of modernization. It is no secret that market economy can have some negative effects on the aspect of morality. With the construction of market economic system, the situation of moral decline has also happened in our society. Only by reconstructing morality, can the value coordinate be provided for the entire society to make people lead a dignified life. The reconstruction of morality relies on various conditions, one of which is seeking roots in the culture, including the awakening of traditional spiritual resources. Therefore, for moral reconstruction, the moral dimensionality of Yimeng spirit has an irreplaceable function.

Thirdly, carrying forward Yimeng spirit is beneficial for us to strengthen the immunity of the culture during the process of globalization, which has an important meaning on cultural self-consciousness and cultural self-confidence. Globalization, as a double-edged sword, brings the wide flow of materials, energies and information, the general communication of people, as well as the transmission, integration and development of cultures; it also causes cultural homogenization and threatens the pattern of cultural diversity. To maintain the regional cultural value and keep the sustainable development of human cultures, we should maximally dig and carry forward regional cultures, which is an indispensable step to face the impact of globalization. The digging and carrying forward of the national spirits, including Yimeng spirit, is an important aspect and step to defend Chinese cultural traditions, and it is also an important way to maintain the unique cultural memories of Chinese nation. This kind of digging and carrying forward itself is a process to obtain the cultural self-consciousness and cultural self-confidence, because through this kind of way we can separate globalization from westernization and construct a pattern of equal dialogues.

\section{CONCLUSION}

At last, carrying forward Yimeng spirit is beneficial for us to open up, keep forging ahead, and struggle during the economic construction and practical work. Those spiritual qualities, such as sacrifice, dedication, struggle, hardworking, plain-living, willingly bearing the burden of hard works, grittiness, etc., are demanded by the revolutionary war time and also by the economic development and market competition during the peaceful construction time. Compared to western modernization process, our modernization has two features: one is that China didn't have any religious tradition like the West, so China's social value system mainly relied on the ethical order based on blood relationship to maintain; the other one is that the process of economic rise was so short that we couldn't reach the matured level culturally, which resulted in a sequelae called "becoming rich fast". The wide socialization of economic communication is gradually and deeply deconstructing the basis of value. How to maximally restrain the spread of money worship, egoism, hedonism and extreme individualism has become the key to save the value world. In this respect, Yimeng spirit can not only provide an effective "antidote", but also become as the spiritual motivation to promote the healthy development of economy and the society.

\section{REFERENCES}

[1] He Zhonghua.2000. "Contemporary Value of Qilu Culture" [J] TheoryStudy.

[2] People's Publishing House.1957. "Complete Works of Marx and Engels: Volume II” [M]. Edited and Printed by People's Publishing House.

[3] People's Publishing House.1995. "Complete Works of Marx and Engels: Volume I" [M]. Edited and Printed by People's Publishing House.

[4] People's Publishing House.1995. "Selected Works of Lenin: Volume IV” [M]. Edited and Printed by People's Publishing House.

[5] People's Publishing House.1991. "Selected Works of Mao Zedong. Volume III" [M]. Edited and Printed by People's Publishing House.

[6] People's Publishing House.1986. "Selected Readings of Mao Zedong's Works: Volume 1" [M]. Edited and Printed by People's Publishing House. 